\title{
Renaissance and Resistance: Modern French Tapestry and Collective Craft
}

Claire O’Mahony, PhD

Claire I R O'Mahony, PhD is an Associate Professor in the History of Art and Design at the University of Oxford and a Fellow of Kellogg College. She is course director of MSt in the History of Design in the Department for Continuing Education which she founded in 2010. Her research explores how public decoration of the French Republic since 1870 articulated regional identity.

\section{Abstract}

Modern tapestry makers articulated aspirations and anxieties about creativity and craft amidst the economic and political instability of twentieth-century France. In 1946 Jean Cassou selected tapestry as the focus for the Musée national d'art moderne's opening exhibition re-defining post-war France to itself and the world. Liberté, a 1943 tapestry from a cartoon drawn by Jean Lurçat inspired by a poem by Paul Éluard, woven clandestinely in the attic rooms of Suzanne Goubely's Aubusson workshop, typifies this narrative. However, the contrast between Lurçat's wartime writings on tapestry and a 1945 photo essay of Aubusson weavers at work by Robert Doisneau highlights the vigorous debates about where to locate this "renaissance" of tapestry, transformed from a courtly luxury into a collective and economically viable national craft industry. Tapestry was renewed as a modern medium through the collaboration of artist-cartoon makers and weaving workshops; the exhibition culture of galleries run by collectors such as Marie Cuttoli of Maison Myrbor, Jeanne Bucher and Denise Majorel of La Demeure; the administrators of the National Manufactures; and the work of art educators and craftworkers, A. Marius Martin and Pauline Peugniez. The embodied experience required to create and to understand tapestry, where individual and collective experience commingle, resonates with Simone De Beauvoir's principle of "situated freedom". In twenty-first century Aubusson, the new initiatives of the Cité de la Tapisserie and the Olympe de Gouges tapestries celebrate and promote these liberties.

\section{Keywords}

Aubusson; Cité de la tapisserie; Marie Cuttoli; Jaques Fadat; Gobelins; Guillaume Janneau; Jean Lurçat; France; Pauline Peugniez; tapestry; weaving

\section{Acknowledgements}

Research for this article was supported by Women in the Humanities TORCH (The Oxford Research Centre in the Humanities), the John Fell Fund and the Department for Continuing Education, University of Oxford and Kellogg College, Oxford. My thanks to Dr Marjan Groot for her invitation to present this research as the keynote lecture for the 2015 Mo Mo Wo conference at the University of Leiden and the staff of the Mobilier National Paris, the Cite de la Tapisserie and the Cercle de la Tapisserie d'Aubusson and the Archives Départmentales de la Creuse, Guéret. 
[In tapestry] the world is made of the best and the worst, the pure and the impure, abstract, base, concrete, domestic or divine, sweet, bitter or salty, forms in the mural tapestry ferment, reflect, join together furiously: defy those who would cast them into a struggle of prerogatives or classes which can be noble or commonplace in form. The great lady of tapestry holds open house, welcomes all comers, all forms, familiar animals, nettles, pittances, ships, pools, brawls, crows, unicorns...Great ladies and stable boys, everything has its place in tapestry...Everything has its hour. (Lurçat [1943] 1951: 58).

In the conclusion to his treatise Designing Tapestry, written amidst the dark days of the Occupation, Jean Lurçat (1892-1966) invokes a collective memory of tapestry resonant with the famous fifteenth-century cycle in the Musée de Cluny, popularly known as the "Lady and the Unicorn" tapestries. The five senses and courtly love are embodied through a graceful interplay of ladies, unicorns, picturesque animals and a "thousand flowers". However, Lurçat repositions this most seigniorial luxury as a total environment wherein polarities, be they sensory or societal, not only warrant representation but also might be reconciled. The conceptualization of the medium of tapestry as a gracious, elite art has obscured its association with the peripatetic, warring nobility of the Middle Ages and the reconstruction of post-war Europe, and as a site for the negotiation of creative authority. Despite the plethora of exhibition displays and cultural writing about tapestry in the twentieth century, these complex objects fell into neglect outside France sitting uncomfortably between the disciplines of art and design history. At best, a few large public commissions which embodied post-war recalibrations of faith and international diplomacy, such as "Christ in Glory" woven in Aubusson for Coventry Cathedral or an abstract composition for the UNESCO building in New York, have generated pictorial assessments of these textiles as manifestations of individual painters' expressivity. ${ }^{1}$ However, this celebration of the painterly practice of the cartoon has obscured provocative debates about the distinctive networks of collective creativity and craft necessary to the making of tapestry which merit revisiting. The multiplicity of sensorial strategies in tapestry, invoking space through scale and texture as well as representation in color and contour, express both individual and collective endeavor. Poised between the rival canons, histories and disciplinary traditions of modern art, design and craft, modern tapestry elucidates the contested place of decoration within modernity (Reed 1996; Anger 2004: 1-32).

\section{Towards a historiography of modern tapestry: Renaissance and Resistance}

The "renaissance" of modern tapestry, as initially characterized by the art critic and administrator Guillaume Janneau (1887-1968), became synonymous with the commemoration of the Resistance and the re-imagination of post-war France. As early as summer 1944, exhibition culture was a vital dimension of the process described as "épuration" through which the taint of Occupation might be negotiated (Wilson 1994; Cone 2001; Wilson 2002). The museum curator, poet and Resistance leader, Jean Cassou (1897-1986) deployed tapestry as the focus of the first exhibition of the Musée nationale d'art moderne after the Liberation which also toured internationally (Musée nationale d'art moderne 1946; Metropolitan Museum of Art 1947; De Lussy 1995). ${ }^{2}$ Alongside 138 historical examples from the fourteenth-century onwards, 61 tapestries made from cartoons by a pantheon of contemporary artists ensured that this "renaissance" of the medium was firmly distanced from any associations with Vichy's promulgation of folklore and craft (Faure 1989). The circle that formed around Lurçat, whom Denise Majorel (1908-2014) encouraged to constitute the Association des Peintres Cartonniers de Tapisserie in 1945, figured prominently in this section (Cassou et al 1957). 
Lurçat's reputation for clandestine radio broadcasts for the Resistance, the war imagery of his designs and his efforts to establish more streamlined production methods to foster new post-war markets for tapestry, earned him a special place in the historiography of modern French tapestry. Two of France's leading museums of tapestry located in the traditional centers of production - in Angers and Aubusson - bear his name, enshrining a narrative of the cartoon painter's primacy. ${ }^{3} \mathrm{~A}$ Life Magazine article with the byline "Modern Painters Revive Old Art" about the 1946 exhibition typifies this apotheosis of Lurçat as the savior of tapestry but the article also exposed underlying tensions about his authority. Its account of Lurçat's new system of numbered color cartoons (rather than the traditional production of a gouache sketch to be interpreted freely by the weavers) intimates the weavers' anxieties over loss of agency: "now the weavers use numbers to match their colors against a design instead of painstakingly comparing them by eye, as they once were forced to do" (Life Magazine, 1946: 80). Did tapestry workshops embrace Lurçat's absolute dominance of the cartoon and reconfiguration of the medium as art as a liberation, as the Life article suggests? A complex network of educators, collectors and weavers suggested a counter-narrative. Drawing attention to the interconnected creativity within tapestry-making since the late nineteenth century, they highlighted the mutuality between painters, makers and consumers and proposed the importance of collective craft within the transformations of modern French national identity and cultural production rather than a Modernist hagiography.

Scholarship on twentieth-century weaving has principally constellated around assessments of modernist projects such as the Bauhaus textile workshops, the Edinburgh Weavers, or the inclusion of painters' cartoons within studies of interwar and post-war European and American art (Golan 1995, 159-62; Troy 2006; Jackson 2012; Smith 2014). These case studies and methodological predilections differ in focus from the concerns within tapestry weaving which had been evolving since the 1880s in France and the collective practices and contrasting economic models which forged them. The nineteenth-century dehumanizing capitalist mechanization of weaving critiqued by Karl Marx in the Grundrisse which T'ai Smith has thoughtfully analysed as motivating the Bauhaus' reconfigurations of weaving into an emancipatory feminine design industry are distinct from the historical context of a collective, mixed-gendered handicraft practice which remained the principal technique within tapestry making in France (Smith 2014: 28-9). In Romi Golan's important study of modernism's engagement with mural art forms, French cartoon-painters are critiqued for failing to arrest the post-war supplanting of Paris by New York as the center of avant-garde practice within this medium. The present argument focuses instead upon internal debates within France that stressed the mutuality of the medium of tapestry, where artists, weavers and patrons expressed distinct ambitions from the individualism of Abstract Expressionism (Golan 2000: 98-118; Golan 2009: 197-214). Tapestry became a form of "art social," integrating the individual and the collective within the Republic through culture theorized by Roger Marx and others in the decades before the First World War. (McWilliam, Méneux and Ramos 2014).

(Figure 1) The arresting photo essay devoted to Aubusson tapestry workshops by Robert Doisneau (1912-94) published in Le Point invites a different set of questions about the craft of tapestry making. Doisneau's images operated within a wide field of representations of textile production in Aubusson which proliferated in populist magazines such as Paris Match, the art press and in Aubusson, a 16-minute documentary film of 1946 by Jean Lods (1903-74) feted at Cannes and in L'Ecran Français (Biro 1946). Such reporting visualised and problematized the changing creative roles within tapestry workshops. One discerns the traditions of distinctive practice in Aubusson; both genders work side by side in a proximity which facilitated a sense of collective fulfillment and selfexpression. The proud austerity of shared making in these intimate attics rebuts the alienation of factory work critiqued by Marx or the repressive gender politics often associated with segregated 
and hierarchically gendered tasks within textile production. As Paris Match reports, these cherished workshop practices had fostered a solidarity which Lurçat's numbered cartoons threatened: "At first the workers of Aubusson protested against what they felt was a degradation of their metier; Lurçat reduced them to mechanical executors" (Kitrosser 1950: 20).

French custodians, most notably the Mobilier National and the Musée de la tapisserie in Aubusson, and scholars of tapestry have explored how the modern re-imagination of the medium emerged through the National Manufactures, state design schools and the marketplace as much as through the interventions of modern artists such as Lurçat (Vaisse 1965; Heng 1990; Mobilier national 2009; Lazaj and Ythier 2012; Froissart 2015). The pages of interwar journals and installations in venues from department stores and railway stations to international expositions and museums suggest how tapestry was positioned within an ideological stance of collectivism rooted in creative freedom amidst the fluctuating hues of French politics since 1918. Specific debates about the practicalities and principles of cooperation within tapestry production capture the medium's distinctive collectivity both in conception and execution but also in the experience of sensoriality in the multiple audiences of the work. This communal "art social" exemplifies the vital role played by folklore and artisanal craft in the continuities and recalibrations of French national culture and identity from the economic constraints of the 1930s, the rupture of the Occupation, to the reconstruction considered in the existing scholarship (Ory 1994; Peer 1998, 135-66; Zdatny 1990).

An ambivalence haunts the liberating rhetoric of Lurçat's exhortation that "everything has its place in tapestry". This rallying cry for individual dissent amidst the dejection of defeat and Occupation resonated with egalitarian resistance in 1943 as well as serving the process of purging and commemorating urgently need for post-war re-calibrations. However, in prioritizing the expressivity of the cartoon painter over creative networks within tapestry production Lurçat risked undermining the integration of individual expression and communal work in tapestry, an important artistic metaphor for democratic France. By contrast, establishment voices such as two directors of the Ecole des Arts Décoratifs in Aubusson, Guillaume Janneau, the critic and arts administrator, and Pauline Peugniez (1890-1987), a Catholic Art Sacré decorator, conceptualized and promoted what Simone de Beauvoir (1908-86) would theorize as "situated freedom", the recognition that the existential individual can only be liberated through freedom for all. ${ }^{4}$ In 1960 amidst the atrocities against fellow women such as Djamila Boupacha enacted during the Algerian War, De Beauvoir reassessed gendered and colonial assumptions within the Kantian philosophy she had embraced in her youth. Her meditations upon individual and collective liberty chime with UNESCO's definition of intangible heritage status (as from 3 November 2003), which was granted to Aubusson weaving in 2009 , that captures this interconnectivity of makers, medium and place in generating "situated freedom." The definition incorporates:

...the practices, representations, expressions, knowledge, skills [...] that communities, groups and, in some cases, individuals recognize as part of their cultural heritage. This intangible cultural heritage, transmitted from generation to generation, is constantly recreated by communities and groups in response to their environment, their interaction with nature and their history, and provides them with a sense of identity and continuity, thus promoting respect for cultural diversity and human creativity (UNESCO, 2003)

The multivalent human interactions within the production and experience of tapestry embodies a notion of individual liberty that depends upon "situated" freedom for each member within the creative network. Equally, the multisensory affect of tapestry forces its audiences to apprehend the situated interactions of body, the object and space involved in the making, dissolving the authority of pictorial spectatorship. A 1943 tapestry named Liberté for the cartoon drawn by 
Jean Lurçat which visualises a poem by Paul Éluard (1895-1952) provides an apposite example through which to consider these questions. The radiance of the creativity of the Resistance heroes Lurçat and Éluard has cast into shadow the story of the object's weaving which was toiled over in secret by now unknown hands in the attic rooms of the atelier of Suzanne Goubely-Gatien (1907-97) in Aubusson. Liberté in its solidarity of conception and production attests not only to the memory of a clandestine act of resistance of a craft network, but the complex and problematic relationship between cartoon designer and weaver that demands attention as Aubusson's UNESCO-validated "Cité de tapisserie" considers the future of tapestry in the twenty-first century.

\section{$\underline{\text { Tapestry production and promotion in mid-century France }}$}

Tapestry engages a nexus of professions to collaborate in its conception and execution: painters and cartoon makers; variously tasked spinners, dyers and weavers; textile entrepreneurs, collectors, consumers and critics. Traditional methods of making are painstakingly slow and expensive; the economic crisis of the 1930s threatened to extinguish France's state-sponsored centers of tapestry production in Paris, Beauvais and Aubusson (Fierens 1933; Martin 1933; Babonneix 1935). Reliance upon government patronage had become controversial both as an unsustainable economic model and a cause of aesthetic stagnation. These pressures prompted both the National Manufactures and independent weaving firms to reassess their materials, production methods, iconography and patronage in order to modernize tapestry as an economically viable and vibrantly creative medium.

A quartet of women directors of private galleries championed modern motifs in tapestry to new private markets for international elite consumption alongside governmental commissions. Their important advocacy and patronage had been occluded by the mid-century privileging of Lurçat, but their contribution can be discerned within recent monographs and exhibitions (Musée départemental de la tapisserie. 1993; Coleman 2000; Paulvé 2010; Shanahan 2014: 228-35). (Figure 2) Maison Myrbor, the fashion and interior design house created by the adventuresome collector, couturier and gallerist Mme Marie Cuttoli (1879-1973) called upon a pantheon of modern artists to provide painted cartoons which were woven in Aubusson studios and displayed internationally. (Croizard 1946: 15-18; Lieberman 1948: 146; Réalités 1959: 40-47, 97). Cuttoli supported a network of women gallerists as well, notably, Jeanne Bucher (1872-1946) whose various projects of the 1930s included tapestry exhibitions with the young Denise Majorel, who entered this circle via the Lurçat brothers (Musée et Université de Strasbourg 1994). Majorel's tapestry exhibition which toured amongst the ruined buildings of provincial French towns in 1945 and her organization of L'Association des peintres cartonniers de tapisserie (APCT) in 1947 culminated in the founding with Madeleine David (d.1980) of the gallery La Demeure in Paris at 30 rue Cambacérès in 1950. This was to become an intellectual and financial haven for generations of fledgling tapestry artists until its closure in 1985 (Denizeau 2007: 21-43). Denise René (1913-2012) also included tapestry in her championing of abstraction in post-war Paris. These galleries principally fostered the fame of cartoon artists, thus buttressing a hagiographic narrative and market values. Nonetheless these exhibitions also prompted thoughtful debates about the relationship between modern artists and traditional weavers. Whilst bemoaning American collectors' predilections for European imports over domestic efforts in his review of Cuttoli's 1936 exhibition at the Bignoux Gallery in New York, E M Benson, associate editor of the American Magazine of Art, exemplifies the recognition of her distinctive contribution to promoting both modernity in cartoon design and the traditions of handwoven tapestries. Benson's closing admonishment against repeating what he deemed the "tragic failure" of the "craft-socialist" William Morris, is preceded by a lucid defense of the need for collaboration between the artist and artisan in tapestry-making: 
The workers who, as Madame Cuttoli reports, first expressed dissatisfaction with the designs, were more justified than Madame Cuttoli may be willing to admit. For what they were asked to do was to translate into a mixture of silk and wool, designs which for the most part completely ignored the structural mechanics of tapestry-making. That they managed to do as well as they did is nothing short of a miracle.[...] If the tapestry is to play an important role in the art of tomorrow, this cannot be accomplished by separating the artist from the weaver, nor by ignoring the potentialities of the machine as a productive unit (Benson 1936: 329-30).

Institutional reform initiatives within France predated both these exhibitions and the interventions of the Lurçat circle. The National Manufactures and state decorative art schools had embarked upon a process of modernization of production methods and motifs in the aftermath of the First World War. Lively debates conducted in the pages of interwar press and the commissions of the National Manufactures reveal contrasting strategies for the reforms of the materials and techniques of production and the pictorial vocabularies of design for modern tapestry. Guillaume Janneau, director of the Mobilier National (1923-45), oversaw the integration of the Beauvais National Manufactures directed since 1917 by Jean Ajalbert (1863-1947) with the Mobilier National in 1935 and the Gobelins by 1937. Janneau and Antoine Marius Martin (1869-1955), director of the Ecole des Arts Décoratifs in Aubusson (1917-30), each proposed rival strategies about how to make contemporary tapestry both more aesthetically and economically accessible (Martin 1933; Ajalbert 1933; Froissart 2011; Froissart 2015). (Figure 3) With the tuition and encouragement of Martin, Aubusson firms revived the distinct medieval traditions in weaving methods which deployed a greater robustness of wool, low warp density and a starker color palette which amidst the financial exigencies of the 1930s became more widespread in the hopes of mitigating the collapse of tapestry production. A comparison of arguments proposed by Lurçat with these earlier 1930s interventions helps to contextualize the implications of these new production methods and his numbered cartoons for creative liberty in the tapestry studio.

\section{Lost in translation: Liberty, the cartoon-artist and the weaver}

Jean Lurçat's unusual hybrid text of 1943 (translated as Designing Tapestry in 1950) succinctly outlined the aesthetic and economic factors facing modern tapestry making in a time of economic constraint. Vacillating between autobiography, cost-benefit analysis and a dramatic dialogue between "the reader" and Lurçat, his treatise opens by affirming three core features distinctive to the medium of tapestry: scale; destination and textural surface. In a musical analogy, he likens the more robust warp density, constrained color and coarser wool used in medieval tapestry - the 1370 Angers Apocalypse attributed to Nicholas Bataille (1330-1405) being his favorite example - to the simple virtue of Gregorian plain chant. Lurçat's polemic echoes a long-standing disenchantment with the predilection to adopt painterly conventions within tapestry: "an art that is sturdy rather than delicate...[a] rough surface where contrasts, general construction, and the general design weigh more on our sensibilities than subtleties of expression and the skill of composition" (Lurçat 1951: 3). Indeed, he borrows detailed economic evidence and histories of weaving from other authors but redeploys them to underpin his own distinct manifesto that involved production by numbered charts (Babonneix 1935; Janneau 1942: 93-102).

Lurçat was aware of renaissance developments in tapestry, as well as the subtle theorizations and modulations of dye hues, developed under Michel Chevreul (1786-1889) in the 
1840s. Chevreul was celebrated by Impressionist and Post-Impressionist painters but within tapestry debates the legacy of painterly principles in dye work had come to be pilloried. Chevreul's scheme divided the seven fundamental colors into 14,400 shades, each of which had to be dyed individually. By 1939, most Gobelins' tapestry cartoons still called upon around 2,667 colors each. This subtlety entailed unsustainable wastage. To work a color, a $250 \mathrm{~g}$ hank $^{5}$ had to be dyed at the cost of 53 francs, even though only $20 \mathrm{~g}$ of each hank would usually have been used. So the dyed wool in 2,667 colours for a single tapestry would cost 141,251 francs, over $80 \%$ of which was unused. Further, by working from a painted cartoon and in a very tight density of weave, the process of production was slow and expensive. Between 1900 and 1910 the complete annual production at Beauvais amounted to 20 square meters costing 38,000 francs per meter. Interested in more efficient models of production, Janneau commissioned Lurçat, Gromaire and Pierre Dubreuil (1891-1970) to visit Aubusson in 1936 to experience working in the reduced number of colors and low density warp traditions of the region. Elie Maingonnat (1892-1966), a native Aubussonnais trained in the commercial sector by the Tabard frères et soeurs firm later director of the Ecole des Arts Décoratifs in Aubusson (1930-58), welcomed the trio of painters, introducing them to such key studios such as his own niece's Atelier Goubely which would produce Liberté in 1943.

Lurçat not only embraced Aubusson working practices but also advocated further streamlined standardization. Weaving density was delimited to 13 threads per centimeter. The color range was narrowed down to 40 shades. The cartoon-painter produced a numbered chart rather than the traditional gouache sketch thereby forcing himself to design in terms of the textural masses of tapestry composition rather than the trompe l'oeil effects of easel painting. Although Lurçat claimed this constraint aligned the cartoon painter and the weaver, in practice numbered charts forced weavers to work obediently to the designer's plan rather than interpreting hues and contours according to his or her own predilections, thereby hastening the weaving process. These exigencies were undoubtedly decisions urged by financial considerations as well as the desire for aesthetic control. Having adopted the numbered cartoon method, by 1939, an average Aubusson weaver was producing a square meter each month rather than in a year as at the National Manufactures. Nonetheless in an essay in a collective volume of published amidst the dark days of 1942, Janneau would warn against the concomitant loss of personal expression for the weaver. Could one save a craft tradition whilst destroying the skill and liberty of the artisan?

Lurçat and his circle were convinced that their programme of constraint would bring the designer, the entrepreneur, the weaver and new audiences for tapestry into a new collective dialogue. Lurçat celebrates the form's distinctness from the "egocentric" illusions of easel painting. He argues that the "incorporation" imposed by tapestry's deeper relationship to the space of the room opens out its expressive potential to a wider audience. Painting had become "a secret society...our language was no longer a means of transmission" (Lurçat 1951: 34), whereas "the demands of [tapestry's] materials, their resistance, their texture, their peculiar light make one look for certain effects which are intrinsic not interchangeable" (Lurçat 1951: 41). Fellow artist, Marc Saint-Saens also insisted upon the distinction between the febrile graphisme of painting and drawing and the rhythmic gestural touch of tapestry (Saint-Saens 1946: 24) and like Lurçat believed that tapestry's tactility was not only pre-conceived by the designer and enacted by the weaver but endured in the multi-sensory experience of audience reception. Lurçat insisted that tapestry elicited a different sort of response. He felt it was an intrinsically collective medium: "This 'goose flesh' cloth has its warmth in contact with the hand, warming the walls so as to not chill the bare shoulders of 
our women...tapestry does not have conventional properties on rigid lines which are inaccessible to the majority, but definite attributes that may be experienced by all" (Lurçat 1943: 2). Lurçat's belief in the collective experience embedded in tapestry can be seen in the development of the Liberté tapestry itself.

The Liberté tapestry of 1943 has become an icon of stoicism and invention under constraint, embodying what Rousso has termed "résistencialisme" (1990). (Figure 4) François Tabard, to whose studio Lurçat had entrusted most of his cartoons, was one of thousands of Frenchmen taken away to Nazi labor camps in 1940 under the notorious Service du Travail Obligatoire. So Suzanne Goubely embraced the risk of weaving Liberté, a design redolent with complex visual and textual challenges to the Nazi occupier, in her studio. Meanwhile Lurçat had secreted himself in the department of the Lot, transmitting clandestine broadcasts from within a medieval ruined fort, Saint Laurent-les-Tours, in which he made his studio and home after the war. The tapestry was executed in rough wool in a few stark hues typifying his ambition to express the fierce, freeing beauty of plain chant in tapestry. The motif of the cockerel was inspired by a humble bird striding in his farmyard and recalled the Gallic pride Lurçat felt was all but forgotten. The cockerel sits atop a radiant sun-like orb of hope which obstructs the dark star of tyranny amidst a repeated pattern of battling clouds. Fragments of Paul Éluard's poem figure throughout the composition; its memorable cadences served as passwords after it was printed as a leaflet to be dropped along with munitions for Resistance groups by parachute in 1943. The poem has 21 stanzas evocative of the voyage from boyhood to the maturity of love, a coming of age, but the coup de foudre of the final verse is that the name written again and again ("J'ecris ton nom") is not that of a desired lover but Liberty. In my conversation with Mme Chevalier who trained in the Goubelys studio in the 1970s, she recounted how Suzanne Goubely recalling Nazi soliders inspecting the workshop when Liberté was on the loom. The reversed image used as a guide in the low warp weaving process meant the provocative poetry inscriptions were undecipherable vouchsafing reprisals for the creative weavers (Chevalier 2015). Liberté accrues much deeper meaning when understood in light of this communal culture of resistance amongst the weavers of the Goubely tapestry workshop as well as the imagination of Lurçat's initial cartoon sketch.

Whereas the creative liberty of the weaving workshop was deemed quaint yet dispensable amidst the aspirations for a post-war tapestry industry championed by Lurçat and his numbered cartoons, it had been the focus of committed interwar debate. At one extreme, Ajalbert ridiculed the legendary status of the weavers of the national manufactures: "The error was propagated that weavers 'interpret'. No. They have only ever copied; the executor never 'interprets'" (1933: 101). Cuttoli rejoiced that "weavers could follow [artists' cartoons] with unprecedented docility" (1929: LXIX). By contrast Martin, the director of the decorative art school in Aubusson, argued that: "only on the day when the weaver is liberated from the servitude of the weight of copying the artist's cartoon will the art of tapestry be renewed...every effort must be made to recover the weaver's traditional liberty" (1934: 444; 449). In his 1942 essay on the Renaissance of French Tapestry, Janneau laments that Cuttoli, Lurçat, Martin all "made the weaver the instrument of the painter" (1942: 100) and had long decried the conception of the artist-cartoon maker as "an artist, a creator, a mind, an Author with a modern pot of water" superior to a fellow "workman" (ouvrier) (1922 cited in Froissart 2015: 10). He aspired to the license Charles Le Brun had accorded his weavers, allowing them to approach "the instrument [of a cartoon] with complete freedom, adding or removing a figure as they saw fit, modifying a group or ground according to their needs skills and resources" (1937, 375-6 cited in Froissart 2015: 20). Indeed my research in Janneau's papers preserved at the 
Mobilier National and in archives preserved in Aubusson and Guéret reveals that he risked his own career, and perhaps more, in the hopes of easing the mass unemployment which befell Aubusson weavers in the 1930 s by devising a vast programme of restoring tapestries, woven furniture and carpets in state buildings. ${ }^{6}$ Janneau in effect created a welfare relief programme using only unemployed Aubusson weavers paid by the Mobilier National (MM 1245, typescript of ministerial circular from A de Monzie September 5, 1933). The vast correspondence Janneau received from destitute weavers hoping for work on the project attests both to the need and to the help provided (MM 1246). (Figure 5) Unlike the four women gallerists, Janneau supported feminine creativity in tapestry making, employing numerous women cartoon artists and weavers, including commissioning a tapestry cycle representing five ages in a woman's life from betrothal to old age from cartoons by Pauline Peugniez (GOB 905; 901; 920; 881/2; 893). The socially engaged ethos of Janneau's project to save the craftspeople and skills of the Creuse ${ }^{7}$ working with a newly formed weavers' collective would later draw the criticism of Vichy politicians (MM 1247). Despite this, Janneau's stewardship of the Mobilier National situated the National Manufactures an instrument of social change for weavers.

Peugniez articulated Janneau's advocacy of mutual respect between cartoon makers and weavers most directly in terms of the re-assessment of the gender and class politics of weaving. In June 1939, Peugniez curated an exhibition at the Petit Palais which included the work of amateurs and children as well as small workshops. In her catalogue essay, she aspires to an ethos of solidarity within tapestry as a collective craft network:

The manufactures of the Gobelins and Beauvais, these grand ladies who are somewhat aloof are not represented in this exhibition: we wanted a form of tapestry which is closer to ourselves and the everyday. Doesn't tapestry originate in the artisanal? She was not born in the mind of a master, but in the baskets of wool of women and weavers; an artist might be called upon someday to provide a sketch, but the executor "embroidered" upon it, a charming word which signifies the invention of ornament around a theme. Everything which creates the fantasy of old tapestries...ripples out from the shuttle, from within the matter of tapestry itself. [...] The imagination of the painter did not invent forms in abstraction that the material and techniques of tapestry needed to attempt to copy; rather the materials and techniques dictated the forms, they triggered the imagination of the artist, it was they who led. Distances little by little began to be marked between the painter and artisan who originally lived side-by-side; the spreading authority of the great personalities cast the secondary artisans into shadow. A Raphael, a Rubens carried tapestry to an appropriate level of grandeur but having taken her so far from the condition of her birth, did this not cause her death?[...]The risk-taking of Aubusson firms will ensure the art of tapestry will live.... when the children of France play with beautiful colored wools, painters will naturally think in tapestry and we will have artisans who sense in their fingertips this fantasy, this fever of invention which was the joy of those artisans of the past (Peugniez: n.p.).

Peugniez reclaims tapestry from the primacy and appropriations of a seigniorial elite and modern male artists for the creativity of women, children and artisans. The dogged, quiet activism of a man of letters and bureaucratic functions and the curatorial interventions of an artist-craftswoman deserve greater recognition in the story of modern tapestry. The opening of the "Cité de la 
tapisserie" in Aubusson rightly does this, honoring the interconnected legacies of weavers, critics, government officials as well as the name of Lurçat.

\section{Epilogue : Collective craft and Aubusson's Cité de la tapisserie}

In the twenty-first century, tapestry is once again center stage in contemporary cultural debate about modernity and making. The advent of the technology of digital programming in machine-loomed tapestry manufacture has attracted contemporary artists and the international art world to the medium whilst UNESCO has committed to the preservation of craft skills as a global intangible heritage. In The Walthamstow tapestry designed by Grayson Perry in 2009 art, craft and globalization intersect. Perry commissioned Chinese craft workers to hand embroider the 15 metre work which the Victoria Miro Gallery exhibited to great acclaim around Britain before facilitating its purchase five years later by the Chinese Academy of Art in Hangzhou (Clark 2014). Critics celebrated the centrality of the laborious craft process to the impact of the work requiring a sustained, situated material interaction between the spectator, artist and craft makers: "the constant emphasis on craft and 'folk' art forces one into actually 'reading' the work closely and repeatedly" (Rose 2009).

Nonetheless Perry abandoned craft methods for The Vanity of Small Differences, his 2012 cycle of 6 tapestries: "I dreamed of being able to do a large pictorial textile with the richness and labor-intensiveness of tapestry, but it seemed too costly and time-consuming to embark on" (Sheets 2012). He opted instead to create digital design files which were then woven on the machine looms of the Flanders Tapestries firm in Belgium. Chuck Close, in collaboration with Magnolia Editions, an Oakland-based firm, have also employed Flanders Tapestries to execute the digital designs. However, mechanical weaving processes have presented somewhat of a false economy as, in tapestry, the market values of originality of conception and execution operate in volatile ways: contemporary tapestry has become at once a handicraft and a multiple. Close identifies the ambivalent marketplace for his tapestries: "The dirtiest word in the art world is 'craft'. Originally my dealer did not want [my Magnolia Edition tapestries]. He told me 'I am not a rug merchant'." (Grant 2013). Paintings and tapestries by contemporary artists draw markedly contrasting auction prices, and the latter do not conform to the art market's norms: "Artists' tapestries are a hybrid of the art multiple market that art collectors, dealers and even the auction houses are having a difficult time knowing what to do with... Part of the reason the art trade tends to shun them is the lack of resale opportunities" (Grant 2013). This hybridity - being both handicraft and a multiple - also impinges on Perry's commendable engagement with audiences beyond the rarefied world of art collecting. His tapestries and televisual interventions honor marginalized, disenfranchised, culturally-alienated identities and experiences within Britain. Perry's prioritizing of the cost-effective promptness of machine weaving creates a problematic dialogue with his tacit critique of the insatiable desire for immediacy and status within contemporary commodity and celebrity culture. Weaving tapestry by hand will always be a slow and expensive practice; the collaboration needed to realize this gestation that brings together art, craft, patronage and engagement, as shown above, is worthy of the time and cost. This effort to represent and valorize tapestry as a means of regenerating economically vulnerable regions is taking place at Aubusson today.

On July 10, 2016, President Hollande inaugurated the "Cité de la tapisserie," which reimagines the former National School of Decorative Art in Aubusson as a centre for education, display and research, fostering a lively culture of commissions for contemporary hand-woven tapestry. (Figure 6) The project flowed from collaborations across the Creuse supported by the subprefect Bernard Bonnelle and the Musée de la tapisserie which helped to secure UNESCO status for the textile community of Aubusson in 2009. A competition to redevelop the 1969 building designed 
by Roger Danis, which had closed its doors in 2005, was held in 2012, awarding the project to Terreneuve architecture studio under the leadership of Nelly Breton, Olivier Fraisse and Cyrille Lemouche, working in collaboration with the "museographes" Frédérique Paoletti and Catherine Rouland. Begun in 2014, the architects reconfigure the post-war brutalism of the site, rather than replacing it with a new structure, and thus highlight an interconnectivity between history and renewal. The building not only preserves and exhibits historic collections, but also is a pedagogic environment which juxtaposes the global practice and origins of tapestry with an engaging installation demonstrating the techniques and the collaboration fundamental to the practice of the medium. New generations of textile makers can gain accredited qualifications in collaboration with the Mobilier National in the Cité's working studio and are encouraged to enter into the annual competitions for tapestry commissions. A striking new skin of vertical, multi-coloured polyester textile membranes in a structure of local Limousin pine designed by Margaret Grey, again suggests both continuity and contemporaneity, clothing the stark brutalism of the original façade in an evocation of the warp and weft of tapestry on a hand loom. ${ }^{8}$ The re-conceptualization of the site and its mission honors the multiple forms of creativity involved in textile production, its heritage and its future innovation.

Echoing the themes of Lurçat's Liberté and UNESCO status, a new cycle tapestries embody these ideals in an inclusive society. (Figure 7) 17 panels represent the 17 points of "Declaration of the Rights of Women and the Female Citizen" written in 1791 by the playwright, abolitionist and feminist politician Olympe de Gouges (1748-93) guillotined under the Terror. Each right is inscribed on a tapestry panel alongside a woman from history expressive of that right. The 17 cartoons were made by a technique of collage and painting by Jacques Fadat (1950-), an artist renowned for his humanist commitment, his scholarship, and creative partnerships he has initiated across the Creuse. Fadat formed the Cercle de la Tapisserie des droits de l'homme in 1987 to enable the creation of a cycle of 6 tapestries measuring 4 meters representing The Rights of Man after designs by Richard Texier (1955-) for the 1989 bi-centenary of the revolution. The 17 designs of the Olympe de Gouges project were created by Fadat in 2007 and are gradually being woven as 2.3 meter-square tapestries with the support of partnerships uniquely constellated in Aubusson convened as the Cercle de la tapisserie. Each tapestry panel is to be woven by hand in Aubusson or neighbouring Felletin

Descendants of the historical woman represented or women who currently serve in French public life in ways expressive of the inscribed Article from the Rights of Women have become "god mothers" to the project. These testimonials promote the project's commitment to honoring women and equality in contemporary life and history: "Exceptional women who made their mark and continue mark the universality of history" (aubusson-j-fadat.com). At the time of writing, three panels are complete: the first panel, Article I of the Declaration (woven by Bernard Battu in 2013-4) embodied by the African-American performer and decorated member of the French Resistance, Josephine Baker, champions the universality of human rights; Olympe de Gouges herself personifies Article X, woven by Alain Chanard in 2014-5 (Figure 8); and the forging of a peaceful Europe after the Second World War is expressed in Article III as the political writer Louise Weil (1893-1983) who championed union. This most recent panel also enlarges the mission of the project in its weaving process: Alain Chanard, master weaver, collaborated with a young weaver Jocelyne Houlbreque, helping to transmit the vulnerable traditions of Aubussonais weaving skills in representing human flesh (Fadat and Chanard 2016). The project thus situates the ideals of liberty in the past, present and future both in the motifs represented and the methods of creative collaboration and mutual respect deployed to execute them. 
In the summer of 2016, the Mobilier national presented one of several exhibitions celebrating Lurçat's painting and tapestry, commemorating the Musée de l'Art Moderne's inaugural exhibition in 1946 devoted to tapestry, Lurçat's death in 1966, and its collaboration with the Cite de la Tapisserie in Aubusson launched in 2016. The unflinching sombre majesty of Lurçat's existential meditations on liberty and loss in the wake of the Second World War once again speaks to a "world made of the best and the worst". Amidst the bloodshed visited on Bastille Day in the boulevards of Nice, 3 days after the inauguration of the Cité de la tapisserie, whilst the mass kidnapping of young girls by Boko Haram in Nigeria in 2014 remains unresolved, these exhibitions rightly honor Lurçat's contributions to the Resistance, post-war art, tapestry and French identity. In the creative community of Aubusson, the cherishing of shared liberty embodied in the collective craft practice of the often anonymous hands of the men and women who think and work in wool, dyes and at the loom perhaps most fully honors Lurçat's 1943 manifesto with which we began: "Great ladies and stable boys, everything has its place in tapestry...Everything has its hour.".

Illustrations:

Figure 1: Aubusson tapestry workshops 1945 photographed by Robert Doisneau (1912-94) illustrated in "La Fresque et la Tapisserie" article by Marc Saint-Saens in Le Point 1945 CAtelier Robert Doisneau.

Figure 2: Tapestry and carpet designs by Jean Lurçat with African sculpture in a vitrine in Maison Myrbor, 17 rue Vignon, Paris circa 1929 founded by Marie Cuttoli, photographed by Thérèse Bonney (Mabel 1894-1978). Charenton-le-Pont, Médiathèque de I'Architecture et du Patrimoine @ Ministère de la Culture - Médiathèque du Patrimoine, Dist. RMN-Grand Palais / Thérèse Bonney @ Droit Etat / Thérèse Bonney (C ADAGP, Paris Réunion des musées nationaux.

Figure 3 : Display of tapestry by Ecole des Arts Décoratifs Aubusson at the Exposition des Arts décoratifs et industriels Paris 1925. Charenton-le-Pont, Médiathèque de l'Architecture et du Patrimoine @Ministère de la Culture - Médiathèque du Patrimoine, Dist. RMN-Grand Palais/image Médiathèque du Patrimoine.

Figure 4: Liberté tapestry 1943 designed by Jean Lurçat; woven at the atelier Goubely, Aubusson. Centre Pompidou - Musée national d'art moderne - Centre de création industrielle, Paris (C) Centre Pompidou, MNAM-CCl, Dist. RMN-Grand Palais / Philippe Migeat.

Figure 5: The 'Hands of Aubusson' display inaugurated July 10, 2016 in the Cité Internationale de La Tapisserie Aubusson/photo E. Roger.

Figure 6: Entrance of the former Ecole Nationale des Arts Décoratifs now the Cité Internationale de La Tapisserie; design by Margaret Grey with Nelly Breton, Olivier Fraisse and Cyrille Lemouche of the Terreneuve architecture studio. Cité Internationale de La Tapisserie Aubusson.

Figure 7: Olympe de Gouges tapestry owned by her birthplace, the city of Montauban, one of 17 panels in the tapestry project designed by Jacques Fadat and woven by Alain Chanard @Georges Martin Qualified European Photographer.

Figure 8: The "tombée" of the tapestry panel for Article X representing Olympe de Gouges held by Jacques Fadat; Chantal de Becker and Alain Chanard in December 2014 CGeorges Martin Qualified European Photographer. 


\section{References:}

Ajalbert, Jean. 1933. Beauvais, basse-lisse. Paris: Denoël.

Anger, Jenny. 2004. Paul Klee and the Decorative in Modern Art. Cambridge: Cambridge University Press.

Archives of the Mobilier National MM 1245; MM 1246; MM 1247; MM 1248.

Babonneix, J. 1935. La crise d'une vieille industrie: Le tapis et la tapisserie d'Aubusson. Paris: Librarie technique et économique.

Benson, E. M. 1936. "Exhibition Reviews" The American Magazine of Art 29(5): 324-336.

Biro, Pierre. 1946. "Le peintre Jean Lurçat et 'Aubusson' - un documentaire Français à Cannes" L'Ecran Français, September 25.

Cassou, Jean; Max Damian; Renée Moutard-Uldry. 1957. La tapisserie française et les peintres cartonniers. Paris: Éditions TEL.

Conversation with Mme Jeanine Chevalier weaver (1960-82) atelier Goubely Aubusson and Mme Hawai, Mobilier National (April 4, 2015).

Clark, Nick. 2014. "Grayson Perry Walthamstow Tapestry acquired by prestigious Chinese Art Gallery." The Independent. May 15. Available at: http://www.independent.co.uk/artsentertainment/art/news/grayson-perrys-walthamstow-tapestry-acquired-by-prestigious-chinesegallery-9380378.html (accessed August 20, 2016).

Coleman, Elizabeth Ann. 2000. "Myrbor and other mysteries: Questions of Art, Authorship and Emigrés" Costume 34: 100-4.

Cone, Michelle. 2001. French Modernisms: Perspectives on Art before, during and after Vichy. Cambridge: Cambridge University Press.

Croizard, Maurice. 1946. "Premier épisode d'une renaissance: I'expérience de Madame Cuttoli" Cahiers d'amis de l'art 9: 15-18.

Dembreville, Nicholas. 2015. "Une Cité de la Tapisserie pour redynamiser Aubusson" Batirama. October 27. Available at: http://www.batirama.com/article/11910-une-cite-de-la-tapisserie-pourredynamiser-aubusson.html (accessed August 20, 2016)

Denizeau, Gerard. 2007. Denise Majorel: Une vie pour la tapisserie. Musée departmental de la Tapisserie: Aubusson.

Conversation with Jaques Fadat artist and Alain Chanard master weaver, Aubusson (September 8, 2016).

Faure, Christian. 1989. Le projet culturel de Vichy Folklore et révolution nationale 1940-44. Lyon: Presses Universitaires de Lyon.

Fierens, P. 1933. "La Creuse et la crise. Art et Technique: Perspectives" Journal des débats, 3.5 October.

Froissart, Rossella. 2011. "Guillaume Janneau, un antimoderne pour un art décoratif" in R. Froissart L. Houssais and J F Luneau (eds.) Du romantisme à l'Art Deco, lectures croisées. Rennes: Presses universitaires. 
Froissart, Rossella. 2015. "Une nouvelle querelle de la tapisserie? Peintres et liciers aux temps de I'Art Deco" La Revue de l'Art 187(1): 9-23.

Golan, Romy. 1995. Modernity and Nostalgia: Art and Politics in France between the World Wars. New Haven; London: Yale University Press.

Golan, Romy. 2000. "L'éternel décoratif: French art in the 1950s" Yale French Studies 98. Special issue The French Fifties (Spring): 98-118.

Golan, Romy. 2009. Muralnomad: The Paradox of Wall Painting, Europe 1927-1957. New Haven; London: Yale University Press.

Grant, Daniel. 2013. "Are rugs becoming the new must have art objects?" The Spectator. July 13. Available at: http://www.spectator.co.uk/2013/07/are-rugs-becoming-the-new-must-have-artobjects/ (accessed August 20, 2016).

Grant, Daniel. 2013. “A Good Yarn: Artists' Tapestries Are Popping Up in Museums, but They're Not Yet Woven Into the Market" The Observer. August 20. Available at: http://observer.com/2013/08/agood-yarn-artists-tapestries-are-popping-up-in-museums-but-theyre-not-yet-woven-into-themarket/ (accessed August 20, 2016).

Heng, Michelle. 1990. "Aubusson et la renaissance de la tapisserie" Histoire de l'art 11: 61-73. Jackson, Lesley. 2012. Alistair Morton and Edinburgh Weavers: visionary textiles and modern art. London: $V$ \& A Publishing.

Janneau, Guillaume. 1942. "La Renaissance de la tapisserie" in La Tapisserie, 93-102. Paris: Éditions du Chêne.

Kitrosser. 1950. "Jean Lurçat à Aubusson" Paris Match, June 10: 18-21.

Lazaj, Jehanne and Bruno Ythier. 2012. Tapisseries 1925 Aubusson, Beauvais, Les Gobelins à l'exposition internationale des arts décoratifs de Paris. Toulouse: Éditions Privat.

Le Point. 1945. "Aubusson et la Renaissance de la Tapisserie." XXXII (mars).

Lieberman, William S. 1948. "Modern French Tapestries" The Metropolitan Museum of Art Bulletin 6 (5): 142-49.

Life Magazine. 1946. "French Tapestries: Modern Painters Revive Old Art." September 15: 80-5.

Loverance, Rowena. 2007. Christian Art. Harvard, MA: Harvard University Press.

Lurçat, Jean. 1951. Designing Tapestry. Translated by Barbara Crocker Welpton. London: Rockcliff.

De Lussy, Florence. 1995. (ed.). Jean Cassou 1897-1986: un musée imaginé. Paris: Bibliothèque de France and Centre Georges Pompidou.

Marso, Lori Jo and Patricia Moynagh. 2006. (eds.). Simone de Beauvoir's Political Thinking. Urbana; Chicago, IL: University of Illinois Press.

Martin, Antoine Marius. 1933. "L'état present et l'avenir de la tapisserie de basse lisse" Revue de l'ameublement 167 (août): 379; 168 (septembre): 431-2; 169 (octobre) 483-4.

Martin, Antoine Marius. 1934. "Le carton modern de tapisserie de haute et de basse lisse" La construction moderne April 1: 442-9. 
Mathias, Martine. 1987. Le Corbusier oeuvre tissé. Paris: Philippe Sers.

McWilliam, Neil, Catherine Méneux and Julie Ramos. 2014. (eds.) L'art social en France de la Révolution à la Grande Guerre. Rennes: Presses Universitaires.

Metropolitan Museum of Art. 1947. French Tapestry. New York: Metropolitan Museum of Art.

Mobilier national. 2009. Élegance et modernité 1908-1958 Un renouveau à la française. Paris: Éditions de la Réunion des musées nationaux.

Musée départemental de la tapisserie. 1993. Aubusson: la voie abstrait: une collaboration entre la galerie Denise René et les ateliers Tabard. Aubusson: Musée départemental de la tapisserie.

Musée et Université de Strasbourg. 1994. Jeanne Bucher: une galerie d'avant-garde, 1925-1946 de Max Ernst à De Staël. Geneva: Skira.

Musée nationale d'art moderne. 1946. La tapisserie française du Moyen Age à nos jours. Paris: Éditions des Musées nationaux.

Ory, Pascal. 1994. La Belle Illusion: Culture et politique sous le signe du Front Populaire. Paris: Plon.

Paulvé, Dominique. 2010. Marie Cuttoli: Myrbor et l'invention de la tapisserie moderne. Paris:

Éditions Norma.

Peer, Shanny. 1998. France on Display: Peasants, Provincials and Folklore in the 1937 World's Fair. Albany: State University of New York Press.

Peugniez, Pauline. 1939. Exposition de vitraux et tapisseries modernes. Paris: Petit Palais.

Réalités. 1959. “Notre Dame d'Aubusson, patronne de l'Art moderne Marie Cuttoli” 162 (juillet): 4047, 97.

Reed, Christopher. 1996. Not at home: The Suppression of Domesticity in Modern Art and Architecture. London: Thames and Hudson.

Rose, Sam. 2009. "Grayson Perry the Walthamstow Tapestry" Studio International. 29 October. Available at: http://www.studiointernational.com/index.php/grayson-perry-the-walthamstowtapestry (accessed August 20, 2016).

Rousso, Henry. 1990. Le Syndrome de Vichy: De 1944 à nos jours. Paris: Seuil.

Shanahan, Maureen. 2014. "Tapis/Tapisserie: Marie Cuttoli, Fernand Léger and the Muralnomad" Konsthistorik tidskrift 83(3): 228-43.

Sheets, Hilary. 2012. "Looms with a View" Art New. September 19. Available at: http://www.artnews.com/2012/09/19/looms-with-a-view/ (accessed August 24, 2016).

Smith, T'ai. 2014. Bauhaus Weaving Theory: From Feminine Craft to Mode of Design. Minneapolis; London: University of Minnesota Press.

Troy, Virginia Gardner. 2006. The modernist textile: Europe and America, 1890-1940. Aldershot: Lund Humphries.

UNESCO, 2003. "Text of the Convention for the Safeguarding of Intangible Cultural Heritage." 29 September - 17 October. Available at: unesco.org/culture/ich/en/convention (accessed September 8, 2016). 
Vaisse, Pierre. 1965. "Sur la tapisserie contemporaine" Information de l'histoire de l'art Mars; Avril: 61-75.

Wilson, Sarah. 1994. "Paris Post War: In Search of the Absolute" in Francis Morris (ed.) Paris Post War: Art and Existentialism 1945-55: 25-53. London: Tate.

Wilson, Sarah. 2002. "Saint Germain des Pres: Anti-Fascism, Occupation and Post-war Paris" in Sarah Wilson (ed.) Paris: Capital of the Arts 1900-1968: 236-49. London: Royal Academy.

Zdatny, Steven. 1990. The Politics of Survival: Artisans in Twentieth-Century France. Oxford: Oxford University Press.

Notes

\footnotetext{
${ }^{1}$ Graham Sutherland made three preliminary sketches and multiple cartoons for the Coventry tapestry which were enlarged by photographic process into horizontal strips to be woven by 12 women weavers at Pinton Frères in Felletin in the Creuse region of central France, 23 x 11 metres, completed 1962 (Loverance 2007: 105). Pinton Frères also wove Le Corbusier's abstract design inspired by the plan of the UNESCO building for its boardroom, 3.5 x 6.8 m, completed in 1956 (Mathias 1987: 90).

${ }^{2}$ This tapestry exhibition travelled around European capitals throughout 1946 and 1947 and on to the Metropolitan Museum of Art New York where it was displayed between 21 November 1947 and 29 February 1948.

${ }^{3}$ Musée Jean Lurçat et de la tapisserie contemporaine Angers was formed in 1968 to house his vast tapestry cycle Le Chant de Monde; the Musée de la tapisserie within the Centre Culturel Jean Lurçat in Aubusson was founded in 1981; with the granting of UNESCO intangible world heritage status in 2009, the institution was renamed the Cité internationale de la tapisserie, see the conclusion of the article (http://www.cite-tapisserie.fr accessed April 18, 2016).

4 "Every activity contains its own freedom, intellectual activity in particular because it seldom repeats itself...the mistake we made was in failing to restrict this concept to its proper limits...we imagine ourselves whole independent agents" (Beauvoir [1960] 1962: 18).

${ }^{5} \mathrm{~A}$ hank is a standard unit of coiled wool yarn.

${ }^{6}$ My thanks to Mme Lérable archivist of the Mobilier National, Mme Catherine Giraud of the Centre de ressources de la Cité internationale de la tapisserie in Aubusson and the Departmental Archives in Guéret for providing such generous access.

${ }^{7}$ The Creuse is a region of central France, in which Aubusson and Felletin are located.

${ }^{8}$ Added over a layer of rock wool insulation, this superstructure also improves sustainability through climate and light level control.
} 